\title{
Airborne measurements of the nitric acid partitioning in persistent contrails
}

\author{
D. Schäuble ${ }^{1,2}$, C. Voigt ${ }^{1,2}$, B. Kärcher ${ }^{1}$, P. Stock ${ }^{1}$, H. Schlager ${ }^{1}$, M. Krämer ${ }^{3}$, C. Schiller ${ }^{3}$, R. Bauer ${ }^{3}$, N. Spelten ${ }^{3}$, \\ M. de Reus ${ }^{2}$, M. Szakáll ${ }^{2}$, S. Borrmann ${ }^{2,4}$, U. Weers ${ }^{5}$, and Th. Peter ${ }^{5}$ \\ ${ }^{1}$ Deutsches Zentrum für Luft- und Raumfahrt, Institut für Physik der Atmosphäre, Oberpfaffenhofen, Germany \\ ${ }^{2}$ Institut für Physik der Atmosphäre, Johannes-Gutenberg Universität Mainz, Mainz, Germany \\ ${ }^{3}$ Institut für Stratosphärenforschung, FZ Jülich, Jülich, Germany \\ ${ }^{4}$ Max-Planck-Institut für Chemie, Mainz, Germany \\ ${ }^{5}$ Institut für Atmosphäre und Klima, ETH Zürich, Zürich, Switzerland
}

Received: 22 May 2009 - Published in Atmos. Chem. Phys. Discuss.: 30 June 2009

Revised: 6 October 2009 - Accepted: 12 October 2009 - Published: 2 November 2009

\begin{abstract}
This study reports the first systematic measurements of nitric acid $\left(\mathrm{HNO}_{3}\right)$ uptake in contrail ice particles at typical aircraft cruise altitudes. During the CIRRUS-III campaign cirrus clouds and almost 40 persistent contrails were probed with in situ instruments over Germany and Northern Europe in November 2006. Besides reactive nitrogen, water vapor, cloud ice water content, ice particle size distributions, and condensation nuclei were measured during 6 flights. Contrails with ages up to $12 \mathrm{~h}$ were detected at altitudes $10-11.5 \mathrm{~km}$ and temperatures $211-220 \mathrm{~K}$. These contrails had a larger ice phase fraction of total nitric acid $\left(\mathrm{HNO}_{3}^{\text {ice }} / \mathrm{HNO}_{3}^{\text {tot }}=6 \%\right)$ than the ambient cirrus layers $(3 \%)$. On average, the contrails contained twice as much $\mathrm{HNO}_{3}^{\text {ice }}$ as the cirrus clouds, $14 \mathrm{pmol} / \mathrm{mol}$ and $6 \mathrm{pmol} / \mathrm{mol}$, respectively. Young contrails with ages below $1 \mathrm{~h}$ had a mean $\mathrm{HNO}_{3}^{\text {ice }}$ of $21 \mathrm{pmol} / \mathrm{mol}$. The contrails had higher nitric acid to water molar ratios in ice and slightly higher ice water contents than the cirrus clouds under similar meteorological conditions. The differences in ice phase fractions and molar ratios between developing contrails and cirrus are likely caused by high plume concentrations of $\mathrm{HNO}_{3}$ prior to contrail formation. The location of the measurements in the upper region of frontal cirrus layers might account for slight differences in the ice water content between contrails and adjacent cirrus clouds. The observed dependence of molar ratios as a function of the mean ice particle diameter suggests that icebound $\mathrm{HNO}_{3}$ concentrations are controlled by uptake of exhaust $\mathrm{HNO}_{3}$ in the freezing plume aerosols in young contrails and subsequent trapping of ambient $\mathrm{HNO}_{3}$ in growing ice particles in older (age $>1 \mathrm{~h}$ ) contrails.
\end{abstract}

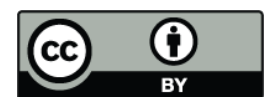

Correspondence to: D. Schäuble (dominik.schaeuble@dlr.de)

\section{Introduction}

Heterogeneous processes such as the uptake of nitric acid $\left(\mathrm{HNO}_{3}\right)$ in cirrus clouds influence the ozone budget in the tropopause region. Results from a global chemistry transport model indicate that $\mathrm{HNO}_{3}$ uptake in cirrus ice particles and subsequent particle sedimentation has the potential to remove $\mathrm{HNO}_{3}$ irreversibly from this region, leading to a large-scale reduction of gas phase $\mathrm{HNO}_{3}$ concentrations (von Kuhlmann and Lawrence, 2006). Popp et al. (2004) and Krämer et al. (2008) suggest, based on in situ measurements, that tropical convective cirrus with a high ice water content have the highest potential to vertically redistribute $\mathrm{HNO}_{3}$. Voigt et al. (2008) show that tropical cirrus clouds at low temperatures can also serve as nuclei for the formation of nitric acid trihydrate (NAT) particles. Kärcher (2005) demonstrates, based on cloud-resolving simulations, that long-lived Arctic frontal cirrus clouds are capable of denitrifying (and partially dehydrating) upper tropospheric air very efficiently at temperatures $<220 \mathrm{~K}$ over vertical regions as large as $3 \mathrm{~km}$. Irreversible removal of gaseous $\mathrm{HNO}_{3}$ reduces the concentrations of the ozone precursor nitrogen oxide $\left(\mathrm{NO}_{\mathrm{x}}=\mathrm{NO}+\mathrm{NO}_{2}\right)$ and hence net ozone production rates at typical upper tropospheric $\mathrm{NO}_{\mathrm{x}}$ levels. Meier and Hendricks (2002) address the sensitivity of this process by means of chemistry box model studies and find reductions in local ozone concentrations of up to $14 \%$.

The interaction of $\mathrm{HNO}_{3}$ and cirrus ice crystals was investigated experimentally during several field campaigns from the tropics to the Arctic (Weinheimer et al., 1998; Schlager et al., 1999; Kondo et al., 2003; Popp et al., 2004; Ziereis et al., 2004; Voigt et al., 2006). Voigt et al. (2006) summarized these measurements in terms of average nitric acid to water molar ratios $\left(\mu=\mathrm{HNO}_{3}^{\text {ice }} / \mathrm{H}_{2} \mathrm{O}^{\text {ice }}\right)$ in cirrus

Published by Copernicus Publications on behalf of the European Geosciences Union. 
ice particles and ice-bound fractions of total nitric acid $\left(\phi=\mathrm{HNO}_{3}^{\text {ice }} / \mathrm{HNO}_{3}^{\text {tot }}\right)$. Kärcher and Voigt (2006) explained the inverse temperature trend of the $\mu$ and $\phi$ data by means of a model describing nitric acid uptake in growing ice crystals (trapping). Trapping refers to the combined effect of mass accomodation and desorption of molecules at an ice crystal surface that grows from the vapor phase by the deposition of water $\left(\mathrm{H}_{2} \mathrm{O}\right)$ molecules, allowing for the burial of adsorbed molecules during surface layer growth. A recent update of the trapping model predicts the steady-state amount of $\mathrm{HNO}_{3}$ trapped in bulk ice particles for a given ice growth rate, assuming Langmuir-type adsorption isotherms, including the underlying adsorption model asymptotically for nongrowing ice particles (Kärcher et al., 2009).

Kärcher et al. (1996) simulate the formation of high levels of $\mathrm{HNO}_{3}$ in jet aircraft exhaust plumes prior to contrail formation. These early $\mathrm{HNO}_{3}$ concentrations are determined by the $\mathrm{NO}_{\mathrm{x}}$ emission index and the engine exit plane concentration of the hydroxyl radical $(\mathrm{OH})$ which acts as the primary oxidant. Arnold et al. (1992) and Tremmel et al. (1998) report the detection of gas phase $\mathrm{HNO}_{3}$ in young aircraft exhaust plumes. Kärcher (1996) demonstrates by means of microphysical simulations that gaseous $\mathrm{HNO}_{3}$ is efficiently transferred into plume aerosols and ice particles during contrail formation. Gao et al. (2004) measured $\mathrm{HNO}_{3}$ in ice particles of a WB-57 aircraft contrail in the subtropics at 14$15 \mathrm{~km}$ altitude. They demonstrated that $\mathrm{HNO}_{3}$ was present in contrail particles at temperatures below $205 \mathrm{~K}$, presumably in the form of NAT, but did not explicitly report ice phase $\mathrm{HNO}_{3}$ concentrations. An experimental quantification of the $\mathrm{HNO}_{3}$ content in contrail ice particles as a function of mean ice particle size, a proxy for the microphysical age of persistent contrails, is lacking.

In this study, we present and interpret in situ observations of reactive nitrogen $\left(\mathrm{NO}_{\mathrm{y}}\right), \mathrm{H}_{2} \mathrm{O}$, as well as microphysical properties of contrails and thin frontal cirrus layers, performed over Germany, the North Sea, and the Baltic Sea during the CIRRUS-III campaign during 23-29 November 2006. During this campaign, the cirrus layers were probed with the Enviscope Learjet for almost $30 \mathrm{~min}$ in the temperature range 210-230 K (24, 28, and 29 November 2006) and 37 contrails were unintentionally sampled for more than $200 \mathrm{~s}$ at temperatures from 211 to $220 \mathrm{~K}$ ( 24 and 29 November). Contrail ages of up to about twelve hours were estimated based on the $\mathrm{NO}_{\mathrm{y}}$ data (Schumann et al., 1998). These observations provide an unprecedented data set on the uptake of $\mathrm{HNO}_{3}$ in persistent contrails.

\section{Instrumentation}

The Learjet performed 5 flights at latitudes between $48^{\circ} \mathrm{N}$ and $68^{\circ} \mathrm{N}$ with instruments measuring $\mathrm{NO}_{\mathrm{y}}, \mathrm{H}_{2} \mathrm{O}$, small ice crystal size distributions, and condensation nuclei $(\mathrm{CN})$. The forward- and backward-facing inlets of the
$\mathrm{NO}_{\mathrm{y}}$-instrument (Ziereis et al., 2000; Hegglin et al., 2006) operated by DLR and ETH Zurich sampled total (gas phase plus enhanced particulate) and gas phase $\mathrm{NO}_{\mathrm{y}}$, respectively. Total reactive nitrogen represents the sum of $\mathrm{NO}_{\mathrm{x}}$ and other nitrogen-containing species in higher oxidation states, $\mathrm{NO}_{\mathrm{y}}=\mathrm{NO}_{\mathrm{x}}+\mathrm{HONO}+\mathrm{HNO}_{3}+\mathrm{HO}_{2} \mathrm{NO}_{2}+2 \mathrm{~N}_{2} \mathrm{O}_{5}+\mathrm{PAN}+\ldots$. Two converter channels are located in the inlet system. Inside these gold tubes, heated to $300^{\circ} \mathrm{C}, \mathrm{NO}_{\mathrm{y}}$ is converted to NO using $\mathrm{CO}$ as the reducing agent (Fahey et al., 1985). The chemiluminescence of the reaction of $\mathrm{NO}$ with $\mathrm{O}_{3}$ is detected with a photomultiplier at a rate of $1 \mathrm{~Hz}$. Before each flight the conversion efficiency of the converters and the sensitivity of the chemiluminescence detector are determined by adding known amounts of $\mathrm{NO}_{2}$ and $\mathrm{NO}$, respectively. The instrument background is measured every ten minutes during the flight. Sampling of particulate $\mathrm{NO}_{\mathrm{y}}$ with the forward-facing inlet depends on the ratio of the flow speed outside and inside the inlet tube as well as on the particle size. To calculate the concentration of particulate (in our case essentially ice phase) reactive nitrogen, $\mathrm{NO}_{\mathrm{y}}^{\text {ice }}=\left(\mathrm{NO}_{\mathrm{y}}^{\text {forw }}-\mathrm{NO}_{\mathrm{y}}^{\text {back }}\right) / \mathrm{EF}_{\mathrm{NO}_{\mathrm{y}}}$, we used the maximum enhancement factor $\mathrm{EF}_{\mathrm{NO}_{\mathrm{y}}}^{\mathrm{max}}=u_{0} / \bar{u} \approx 119 \pm 12 \quad\left(u_{0}=\right.$ aircraft true air speed, $\bar{u}=$ inlet flow speed; numerical values for 24 November) (Belyaev and Levin, 1974) for cirrus observations. This approximation may introduce errors of less than $8 \%$ in the $\mathrm{EF}_{\mathrm{NO}_{\mathrm{y}}}$ for observed ice crystal mean diameters $(d>14 \mu \mathrm{m})$. In contrails containing smaller ice particles, we used a size-dependent relationship for $\mathrm{EF}_{\mathrm{NO}_{\mathrm{y}}}(d)$ (Belyaev and Levin, 1974). Aerosol particles smaller than $1 \mu \mathrm{m}$ in diameter were sampled with the forward- as well as the backward-facing inlet. Thus, they do not contribute to the $\mathrm{NO}_{\mathrm{y}}^{\text {ice }}$ signal. Larger $\mathrm{NO}_{\mathrm{y}}$-containing aerosol particles, if present, are still likely smaller than most ice particles and are therefore associated with lower enhancement factors $(\sim 63 \%$ of $\mathrm{EF}_{\mathrm{NO}}^{\max }$ for $\left.d=3 \mu \mathrm{m}\right)$, resulting in a minor contribution to the $\mathrm{NO}_{\mathrm{y}}^{\text {ice }}$ signal.

The $\mathrm{NO}_{\mathrm{y}}$ detection limit in particles is $0.8 \mathrm{pmol} / \mathrm{mol}$ on 24 and 29 November and $0.6 \mathrm{pmol} / \mathrm{mol}$ on 28 November, as derived from the difference of the forward- and backwardfacing channel signals outside clouds divided by the enhancement factor.

Nitric acid was not measured directly during CIRRUSIII, except during the flight on 28 November where we used a nylon filter in the aft-facing inlet to retain $\mathrm{HNO}_{3}$ and thus derive the gas phase $\mathrm{HNO}_{3} / \mathrm{NO}_{\mathrm{y}}$ ratio. As the cirrus clouds on 24 and 29 November were detected slightly below the tropopause (ozone mixing ratios $<90 \mathrm{nmol} / \mathrm{mol}$ ), we employed a value of $0.45 \pm 0.2$, corresponding to the mean gas phase $\mathrm{HNO}_{3} / \mathrm{NO}_{\mathrm{y}}$ ratio at these ozone levels during the flight on 28 November. Talbot et al. (1999) and Neuman et al. (2001) measured both $\mathrm{HNO}_{3}$ and $\mathrm{NO}_{y}$ obtaining mean gas phase $\mathrm{HNO}_{3} / \mathrm{NO}_{\mathrm{y}}$ ratios of 0.35 and $0.2-0.5$, respectively. However, they sampled at lower altitudes down to 8 and $7 \mathrm{~km}$, respectively. 
In young contrails $\mathrm{NO}_{\mathrm{x}}$ constitutes the major fraction of $\mathrm{NO}_{\mathrm{y}}$. A microphysical plume model study (Meilinger et al., 2005) including detailed heterogeneous aerosol and ice phase chemistry indicates that the chemical conversion into $\mathrm{HNO}_{3}$ is small in contrails in terms of the gas phase $\mathrm{HNO}_{3} / \mathrm{NO}_{\mathrm{y}}$ ratio $(\approx 1 \%)$ within the first ten hours after emission due to heterogeneous dehoxification and production of HONO. Entrainment of ambient $\mathrm{HNO}_{3}$ is supposed to be the dominant process controlling the gas phase $\mathrm{HNO}_{3}$ concentration in such contrails. Thus, we used the ambient $\mathrm{HNO}_{3}$ concentration as an approximation for the concentration inside contrails. Further, we assumed that $\mathrm{HNO}_{3}$ accounts for $100 \%$ of $\mathrm{NO}_{\mathrm{y}}$ in ice particles in cirrus clouds as well as in contrails. $\mathrm{N}_{2} \mathrm{O}_{5}$ and $\mathrm{HO}_{2} \mathrm{NO}_{2}$ are quickly photolyzed during daytime and the uptake of PAN and HONO on ice crystals is probably small compared to $\mathrm{HNO}_{3}$ (Bartels et al., 2002).

Total water $\left(\mathrm{H}_{2} \mathrm{O}_{\text {tot }}=\right.$ gas phase plus enhanced particulate water) was measured with the forward-facing inlet of the Fast In situ Stratospheric Hygrometer (FISH) (Zöger et al., $1999)$ using the Lyman- $\alpha$ photofragment fluorescence technique. Water vapor $\left(\mathrm{H}_{2} \mathrm{O}\right)$ was detected with the OJSTER instrument (Open-path Jülich Stratospheric TDL ExpeRiment) (Schiller et al., 2008) by measuring the amount of laser light absorption in gaseous water molecules at a wavelength of $1.37 \mu \mathrm{m}$. The data of the OJSTER instrument were adjusted to the FISH instrument data in order to reach agreement in observations outside of clouds. On average, the OJSTER data were increased by $15 \mu \mathrm{mol} / \mathrm{mol}$ in cirrus clouds. The ice water content (IWC) was derived from IWC $=\left(\mathrm{H}_{2} \mathrm{O}_{\text {tot }}{ }^{-}\right.$ $\left.\mathrm{H}_{2} \mathrm{O}\right) / \mathrm{EF}_{\mathrm{H}_{2} \mathrm{O}}$. $\mathrm{EF}_{\mathrm{H}_{2} \mathrm{O}}$ was around 6 during CIRRUS-III. According to Schiller et al. (2008) the detection limit of the IWC is temperature dependent and averages to $\sim 0.1 \mathrm{mg} \mathrm{m}^{-3}$ in the range $210-230 \mathrm{~K}$. The uncertainty in IWC is $15 \%$.

The number concentration and size distribution of particles with diameters $2.8-29.2 \mu \mathrm{m}$ were measured with the Forward Scattering Spectrometer Probe FSSP-100 (Borrmann et al., 2000). The particles were grouped into seven size bins and assumed to be spherical and composed of pure ice. The FSSP-100 data were used in combination with $\mathrm{CN}$ and $\mathrm{NO}_{\mathrm{y}}$ measurements to identify contrails and cirrus (Sect. 3), i.e. to decide upon the presence or absence of ice crystals. Therefore, possible uncertainties associated with the FSSP-100 data are not critical for this purpose. We detected cirrus clouds from correlated increases in the FISH and FSSP-100 signals: cirrus clouds were observed either if the IWC was above $0.25 \mathrm{mg} \mathrm{m}^{-3}$ or if $0.1 \mathrm{mg} \mathrm{m}^{-3}<$ IWC $<0.25 \mathrm{mg} \mathrm{m}^{-3}$ and the FSSP-100 particle concentration $>0$.

\section{Identification of contrails}

Contrails were identified from distinct simultaneous shortterm increases in the time series of the concentrations of $\mathrm{NO}_{\mathrm{y}}^{\text {gas }}, \mathrm{NO}_{\mathrm{y}}^{\text {tot }}, \mathrm{CN}$ ( $>5 \mathrm{~nm}$ diameter, not discussed here), and ice particles. The concurrence of these four signals and their strong increase and decrease within few seconds enabled a separation of contrails from cirrus clouds that were not recently affected by aviation. Lower limits of $0.1 \mathrm{nmol} / \mathrm{mol}$ for $\Delta \mathrm{NO}_{\mathrm{y}}^{\mathrm{gas}}$ and $100 \mathrm{~cm}^{-3}$ for $\Delta \mathrm{CN}$ were used as thresholds in this identification. These limits correspond to a contrail age of approximately $12 \mathrm{~h}$ assuming homogeneous dilution and sampling through the contrail core $\left(\mathrm{t}[\mathrm{s}]=\left(525[\mathrm{nmol} / \mathrm{mol}] / \Delta \mathrm{NO}_{\mathrm{y}}^{\text {gas }}[\mathrm{nmol} / \mathrm{mol}]\right)^{1.25}, \mathrm{An}-\right.$ derson et al., 1999). As contrails were not the primary focus of the CIRRUS-III campaign, we consider the spatial sampling to be random in terms of angles relative to the contrail axis and distances from the contrail core.

The amplitudes of the instrument peaks decrease with increasing contrail age and, for a given age, with distance from the contrail core. Contrails often exhibit significant spatial inhomogeneities in structure and dilution properties. The detection of contrails older than $12 \mathrm{~h}$ as well as the merging of several individual contrails may result in an extended contrail detection signal. Together, this introduces considerable uncertainty in the exact determination of contrail age from plume dilution data which is difficult to quantify.

We regard the probed cirrus clouds as upper tropospheric ice clouds that were not influenced by aircraft emissions within the last $12 \mathrm{~h}$ of their lifetime. It cannot be ruled out that part of the cirrus were actually older (age $>12 \mathrm{~h}$ ) contrails. That being said, most of the observed contrails were embedded in thin cirrus clouds. In 79\% of all cases either the FSSP or the FISH signal are $>0$ before and after the contrail encounter which suggests the presence of ice crystals. 53\% of the contrails were located in cirrus that meet the robust cirrus criterion mentioned in Sect. 2. This implies that for statistical reasons our data set does not allow us to compare properties of isolated contrails with those of contrails in cirrus clouds.

\section{Nitric acid partitioning and ice water content in con- trails}

European Centre for Medium-Range Weather Forecasts analyses indicate that the upper regions of frontal cirrus layers were probed on 24 and 29 November, whereas on 28 November the observations originate from deeper inside cirrus clouds. On 24 November large parts of central Europe were covered by the cirrus. The cirrus layers were much more stretched out with a large North-South extension on 28 and 29 November. As an example of our suite of data, Fig. 1 shows a typical time series of data from the flight on 24 November over Germany. In this and the following section, we further present model results providing explanations of the observed uptake of $\mathrm{HNO}_{3}$ in contrails and the cirrus layers.

Figure 2 (top panel) illustrates the decrease of the ice phase fraction of total nitric acid $(\phi)$ with increasing temperature. 


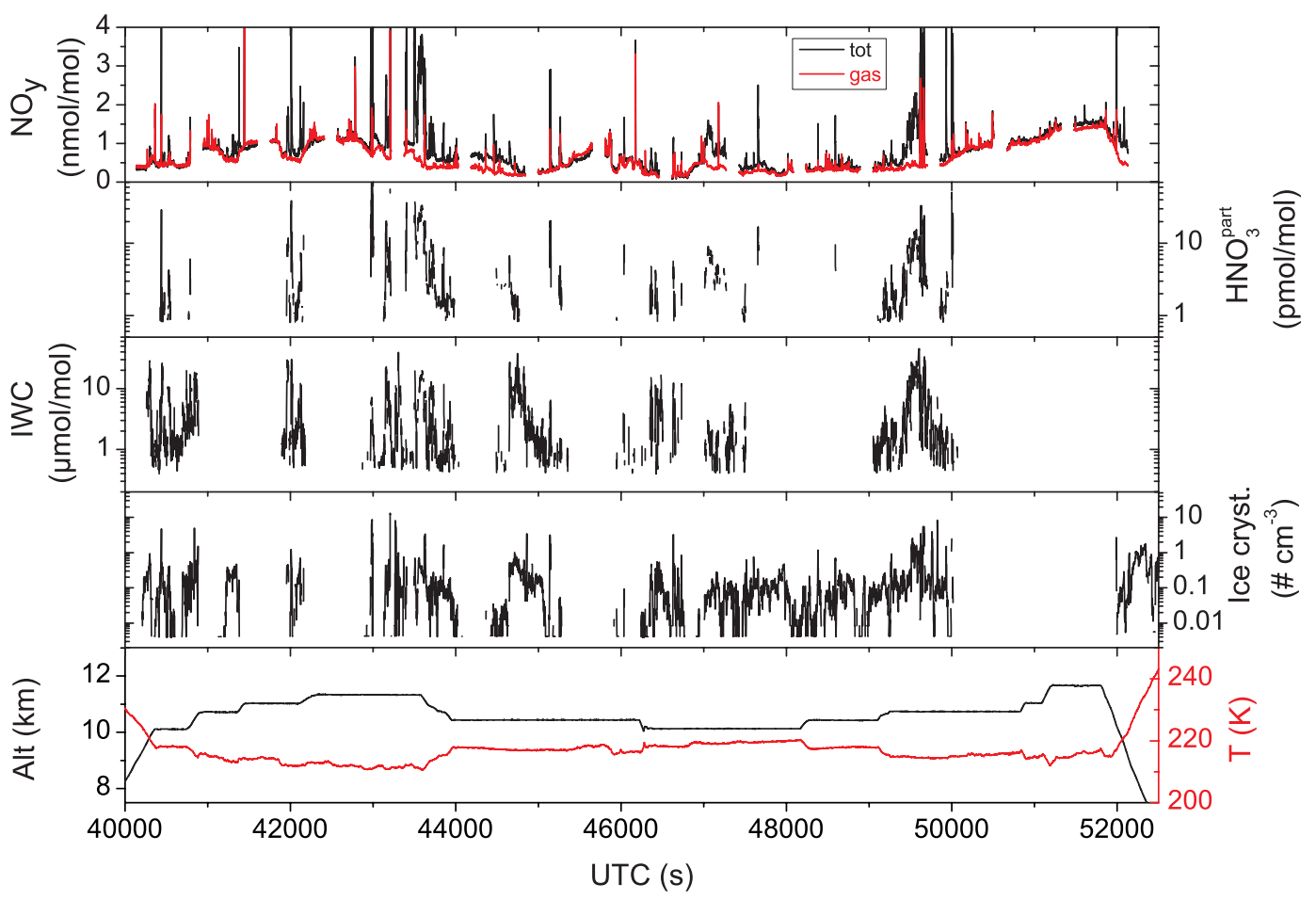

Fig. 1. Time series of gas phase and total $\mathrm{NO}_{y}$ (gas phase plus enhanced ice phase), ice phase $\mathrm{HNO}_{3}$ volume mixing ratios, ice water content (IWC), number densities of ice particles with approximate diameters between 2.8 and $29.2 \mu \mathrm{m}$, as well as altitude and temperature for the flight on 24 November 2006. Gaps in the $\mathrm{NO}_{\mathrm{y}}$ measurements are due to calibration procedures.

This dependence agrees with previous observations but almost all of the observed $\phi$ values in cirrus clouds (grey circles) are below the mean of previous measurements (Kärcher and Voigt, 2006). This is probably due to the relatively low IWCs measured during CIRRUS-III (Fig. 2, bottom panel) and the positive correlation between $\phi$ and IWC (Krämer et al., 2008). Further, the $\mathrm{HNO}_{3}$ gas phase partial pressures were higher $\left(4.7 \times 10^{-8} \pm 1.3 \times 10^{-8} \mathrm{hPa} \sim 0.2 \mathrm{nmol} / \mathrm{mol}\right)$ than the average of the other campaigns $\left(2 \times 10^{-8} \mathrm{hPa}\right)$ (Kärcher and Voigt, 2006). The uncertainty of the gas phase $\mathrm{HNO}_{3} / \mathrm{NO}_{\mathrm{y}}$ ratio (Sect. 2) introduces an uncertainty in $\phi$ (time resolution $1 \mathrm{~s}$ ) of about a factor of 2 .

On average, contrails were found to have larger $\phi$ values than the cirrus layers under similar conditions (black and red squares, respectively). This is further illustrated with the help of probability distributions of $\phi$ displayed in Fig. 3a. At temperatures between 211 and $220 \mathrm{~K}$, contrail ice particles contained on average $6 \%$ (cirrus $3 \%$ ) of the total nitric acid. Twelve young contrails with $\Delta \mathrm{NO}_{\mathrm{y}}^{\text {gas }}>0.75 \mathrm{nmol} / \mathrm{mol}$, corresponding to ages $<1 \mathrm{~h}$, had even larger ice phase nitric acid fractions $(9 \%)$. The maximum $\phi$ measured in contrails was $22 \%$.

The gas phase equivalent mixing ratio of nitric acid in ice, $\mathrm{HNO}_{3}^{\text {ice }}$, is $14 \mathrm{pmol} / \mathrm{mol}$ in contrails compared to $6 \mathrm{pmol} / \mathrm{mol}$ in the cirrus layers. The mean $\mathrm{HNO}_{3}^{\text {ice }}$ in the young contrails is $21 \mathrm{pmol} / \mathrm{mol}$. Our finding that the absolute amount of $\mathrm{HNO}_{3}^{\text {ice }}$ in contrails is larger than in cirrus could be linked to differences in the ice formation process (Sect. 5).

Figure 2 (middle panel) shows the temperature dependence of the ice phase molar ratios of nitric acid and water $(\mu)$ in contrails (red circles) and in the surrounding cirrus layers (grey circles) that were not recently influenced by aviation. The $\mu$ values generally increase with decreasing temperature, as the probability of $\mathrm{HNO}_{3}$ molecules to escape from the growing ice surfaces after adsorption is reduced at low temperatures leading to more efficient trapping of $\mathrm{HNO}_{3}$ (Kärcher and Voigt, 2006).

The curves are results from a recent update of the trapping model now accounting for possible surface saturation upon adsorption at high $\left(>2 \times 10^{-8} \mathrm{hPa}\right) \mathrm{HNO}_{3}$ partial pressures (Kärcher et al., 2009), causing a weaker temperature dependence of $\mu$ than estimated by the previous model (Kärcher and Voigt, 2006). The dashed and solid model curves were computed for $\mathrm{HNO}_{3}$ partial pressures of $3 \times 10^{-8} \mathrm{hPa}$ and $6 \times 10^{-8} \mathrm{hPa}$, respectively, roughly capturing the range of measured values occurring in contrails and cirrus (see above). The trapping model bounds the observed mean $\mu$ values in cirrus (black squares) very well at $211-220 \mathrm{~K}$. The model assumes temperature-dependent mean ice particle growth rates (net supersaturations) to estimate steady-state molar ratios. Deviations of individual data points from the mean model curves are likely caused by variable growth/sublimation histories of the observed ice 
particles. Further, even in cirrus the $\mu$ of small ice crystals may be strongly influenced by the composition of the freezing aerosol (Sect. 5). As for the data points above $220 \mathrm{~K}$, the low $\mu$ suggests that these ice particles have grown at low $\mathrm{HNO}_{3}$ partial pressures. The relatively high IWC may imply that a considerable number of large ice crystals have sedimented from their formation region depleted in $\mathrm{HNO}_{3}$ into the measurement region. Despite these non-local effects the data are still captured by the lower limit of trapping estimated in Kärcher and Voigt (2006).

The mean $\mathrm{HNO}_{3} / \mathrm{H}_{2} \mathrm{O}$ molar ratio in contrails of $4 \times 10^{-6}$ is found to be approximately twice as large as in the cirrus layers $\left(2 \times 10^{-6}\right)$, which is illustrated by means of the probability distribution of $\mu$ (Fig. 3b). The increase in mean $\mu$ is mainly caused by the data points below $215 \mathrm{~K}$, compare red and black squares in Fig. 2 (middle panel). This difference is roughly consistent with the difference in the mean $\mathrm{HNO}_{3}^{\text {ice }}$ per particle (see above).

The IWC of contrails and cirrus clouds versus temperature is shown in Fig. 2 (bottom panel). Compared to the comprehensive compilation of IWCs by Schiller et al. (2008), based on a large number of in situ measurements at midlatitudes (mean values indicated by the solid curve), the IWC observations on 24 and 29 November below $220 \mathrm{~K}$ appear to be slightly lower for the following reasons. First, thin ice clouds with IWCs as low as $0.1 \mathrm{mg} \mathrm{m}^{-3}$ were included in our data set derived from simultaneous FSSP and total water increases. In addition, in the upper region of frontal cirrus layers, where the data were taken, ice nucleation is supposed to take place and sedimentation of large ice particles out of these layers keeps the IWC small. Finally, there may be entrainment of dry air from above and a reduced IWC arises while crossing cloud free patches within the $200 \mathrm{~m}$ (1 s) measurement interval. The solid curve marks the average values obtained by probing the whole vertical extension of a population of cirrus clouds (Schiller et al., 2008) and is therefore located above our mean IWCs (black squares) below $220 \mathrm{~K}$. Above $220 \mathrm{~K}$ our IWC data were taken deeper inside a cirrus cloud and the respective means are therefore in better agreement with the solid curve. The fact that the trapping model seems to overpredict $\mu$ at higher temperatures (curves not shown in Fig. 2, middle panel) may be tied to the impact of sedimentation and more strongly varying ambient conditions throughout the probed cirrus clouds, which is much less pronounced in the upper layers probed at lower temperatures.

The contrails have a slightly larger mean IWC (red squares) than the cirrus clouds, 1.8 and $1.3 \mathrm{mg} \mathrm{m}^{-3}$, respectively. The IWC of young contrails $2.9 \mathrm{mg} \mathrm{m}^{-3}$ is more than twice the cirrus mean. According to plume dilution estimates derived from large-eddy simulations of aircraft wake vortex development (Gerz et al., 1998), the $\mathrm{H}_{2} \mathrm{O}$ aircraft emissions become unimportant for contrails older than a few minutes. So most of the $\mathrm{H}_{2} \mathrm{O}$ in contrail ice condenses from the ambient air during ice particle growth and differences between contrail and cirrus IWCs are expected to diminish over time.

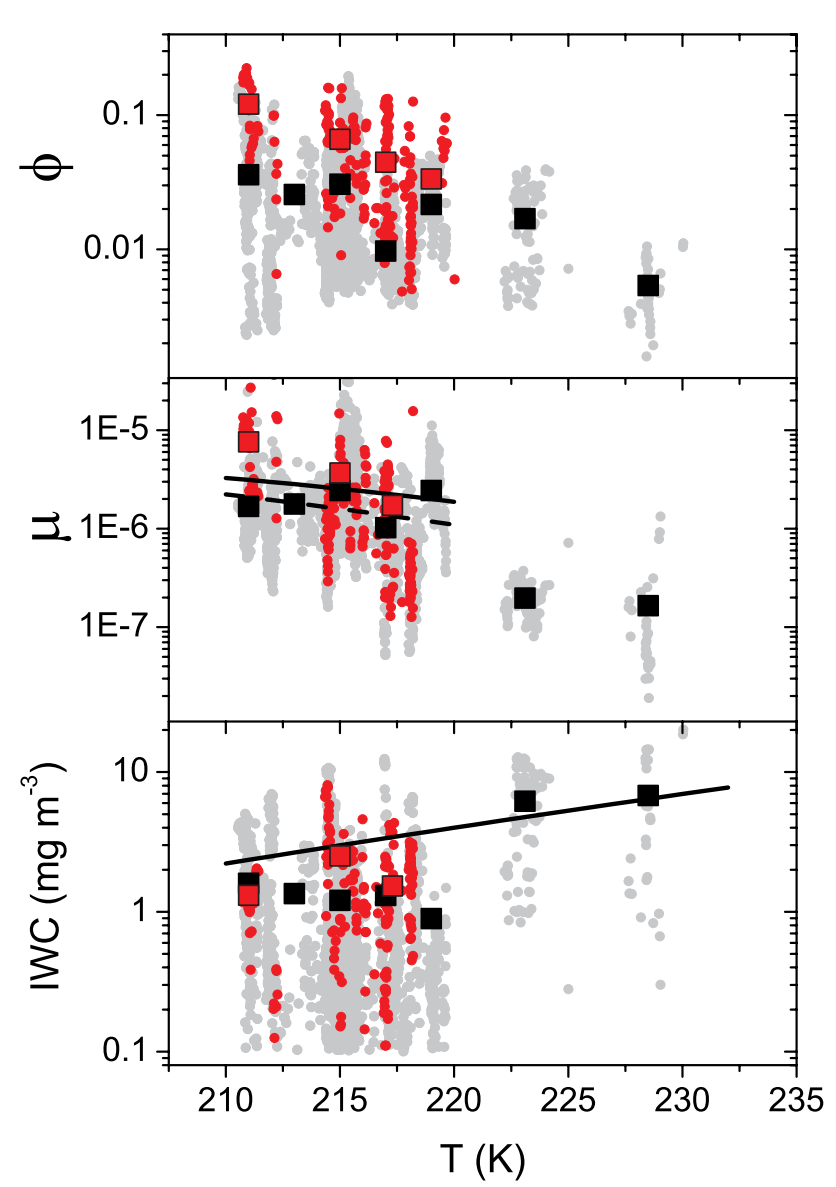

Fig. 2. The temperature dependence of the (top) ice phase fraction of total nitric acid $\left(\phi=\mathrm{HNO}_{3}^{\text {ice }} / \mathrm{HNO}_{3}^{\text {tot }}\right)$, (middle) molar ratio of nitric acid to water in ice particles $\left(\mu=\mathrm{HNO}_{3}^{\text {ice }} / \mathrm{H}_{2} \mathrm{O}^{\text {ice }}\right)$, and (bottom) ice water content (IWC) of contrails (red circles) and cirrus clouds (grey circles). Squares are means over $2 \mathrm{~K}$ temperature bins. For $\mu$ and IWC in contrails the warmest bin is centered at $217.3 \mathrm{~K}$ (instead of $217 \mathrm{~K}$ ) to comprise the measurements at temperatures slightly higher than $218 \mathrm{~K}$. Curves in the middle panel are results from the trapping model evaluated at $\mathrm{HNO}_{3}$ partial pressures of $3 \times 10^{-8} \mathrm{hPa}$ (dashed curve) and $6 \times 10^{-8} \mathrm{hPa}$ (solid curve) at temperatures where contrails were detected (Kärcher et al., 2009). The curve in the bottom panel depicts the mean cirrus IWCs based on a large number of in situ measurements at midlatitudes (Schiller et al., 2008).

We additionally report a striking difference between measured contrail and cirrus cloud ice particle number densities in the FSSP-100 size range $2.8-29.2 \mu \mathrm{m}$ in diameter, $1.5 \mathrm{~cm}^{-3}$ and $0.2 \mathrm{~cm}^{-3}$, respectively. We are aware of the fact that shattering of large $(d>50 \mu \mathrm{m})$ ice crystals at the front end of the FSSP instrument may artificially enhance the measured number concentrations (Heymsfield, 2007; De Reus et al., 2009). However, shattering is probably not affecting the above values to a great extent, as the concentrations of such large particles in the contrails and 

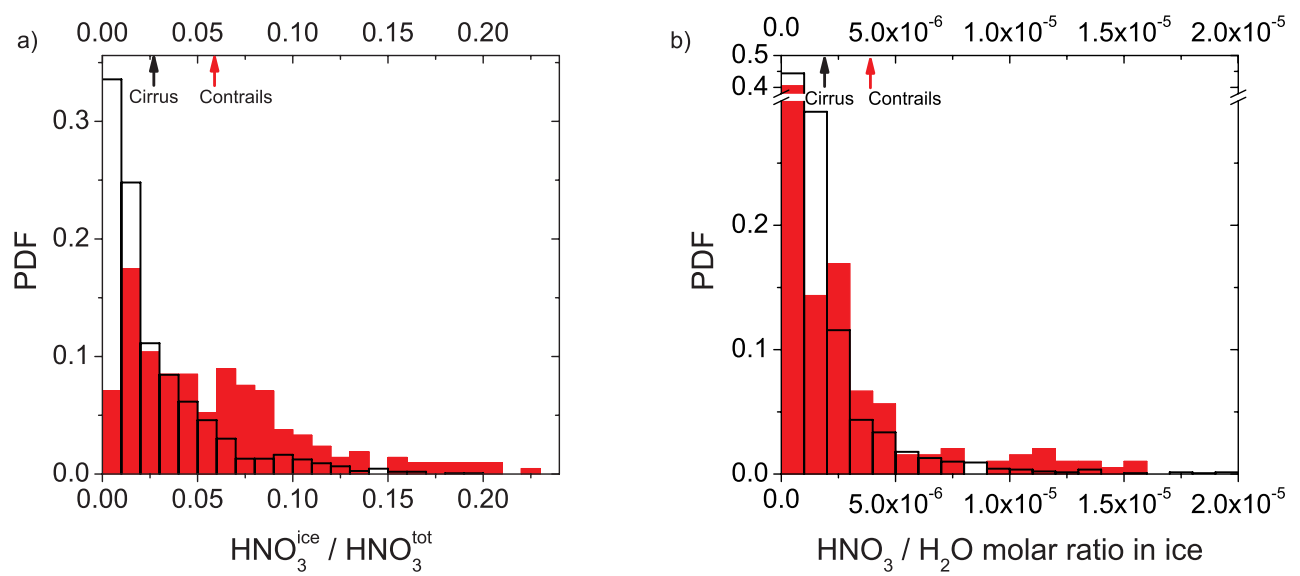

Fig. 3. Normalized probability density functions of the ice phase fraction of total $\mathrm{HNO}_{3} \phi$ (a) and the $\mathrm{HNO}_{3} / \mathrm{H}_{2} \mathrm{O}$ molar ratio in ice $\mu$ (b) for contrails (red) and cirrus clouds (transparent). Arrows indicate the means for the temperature range (211-220 K) where contrails occurred.

in the nucleation layers of cirrus are presumably very small (Schröder et al., 2000). More robust conclusions would be possible when using cloud probes unaffected by shattering and extending the size distribution measurements to diameters $>30 \mu \mathrm{m}$.

\section{Nitric acid uptake in developing contrails}

Given the limited amount of contrail data, it is unclear whether the systematic differences in ice phase fraction and molar ratios in ice presented in Sect. 4 are representative. Nevertheless, sorting the molar ratio data as a function of the mean ice particle size enables us to study the $\mathrm{HNO}_{3}$ uptake process in contrails in more detail.

Figure 4 shows the molar ratios (grey circles) along with the mean (black squares) and median (grey squares) values of the contrails probed during CIRRUS-III as a function of the mean ice particle diameter. We associate rough estimates of the contrail age with the mean diameter, as indicated in the figure. The contrail age is calculated according to Sect. 3 and linked to the mean ice crystal diameter with a linear regression for contrails younger than $1 \mathrm{~h}$. In persistent contrails, the mean size increases due primarily to uptake of $\mathrm{H}_{2} \mathrm{O}$ from the gas phase (depositional growth). The measurements show a clear trend of decreasing $\mu$ with increasing mean size or age. Young contrails with ages $10-15 \mathrm{~min}$ and mean diameters $\sim 7 \mu \mathrm{m}$ have a mean $\mu \approx 10^{-5}$, while older contrails with ages $>1 \mathrm{~h}$ and mean diameters $>10-15 \mu \mathrm{m}$ exhibit values closer to the mean $\sim 2 \times 10^{-6}$ of the cirrus data.

Using campaign-average contrail temperature $(216 \mathrm{~K})$ and $\mathrm{HNO}_{3}$ partial pressure $\left(\sim 5 \times 10^{-8} \mathrm{hPa}\right)$, the updated trapping model (Kärcher et al., 2009) predicts an average molar ratio $\mu_{\infty} \approx 2 \times 10^{-6}$ (dash-dotted curve), consistent with the cirrus observations (middle panel in Fig. 2 and Fig. 3b) and the older contrail data in Fig. 4. Increasing the partial pressure would not significantly increase $\mu$ because the adsorption of $\mathrm{HNO}_{3}$ becomes limited by a monolayer surface coverage during trapping. Hence, trapping of low levels of entrained ambient $\mathrm{HNO}_{3}$ by the growing contrail ice particles is not capable of explaining the high molar ratios exceeding $10^{-5}$ in young contrails.

How are the high molar ratios brought about? We argue that a high concentration of $\mathrm{HNO}_{3}$ had already entered the ice particles during contrail formation, when they are very small (mean diameters $\sim 1 \mu \mathrm{m}$ ), leading to very high molar ratios. Subsequent depositional growth increases the size per ice particle, while trapping in young contrails (mean diameters $1-10 \mu \mathrm{m}$ ) only adds a small contribution to the $\mathrm{HNO}_{3}$ content per particle; both effects cause $\mu$ to decrease in this phase of contrail development. Further growth to larger sizes diminishes the role of the initially high molar ratios and trapping takes over the dominant part in determining $\mu$. These processes are illustrated by the model curves as explained below.

Before we quantify the modeled $\mu$ dependence shown in Fig. 4 in more detail, we note that similar arguments were used to explain the in situ observations of high molar ratios of $\sim 5 \times 10^{-5}$ in nascent cirrus ice particles forming and growing at temperatures near $202 \mathrm{~K}$ and $\mathrm{HNO}_{3}$ partial pressures similar to those encountered during CIRRUS-III (Voigt et al., 2007). In this case, it was proposed that sulfate aerosol particles dissolve large amounts of gaseous $\mathrm{HNO}_{3}$ prior to freezing. Assuming that about half of the dissolved $\mathrm{HNO}_{3}$ remained in the ice particles after freezing, this led to initial molar ratios $\sim 0.01$. We suggest that the same processes act in contrails.

Freezing aerosol surface areas, ice supersaturations, and $\mathrm{HNO}_{3}$ partial pressures are higher during contrail formation than during cirrus formation. Contrail ice particles form from plume particles that efficiently dissolve exhaust $\mathrm{HNO}_{3}$ prior to ice formation (Kärcher, 1996). We estimate the nitric acid to water molar ratio to be $\mu_{0} \approx 0.03$ in the freezing plume 


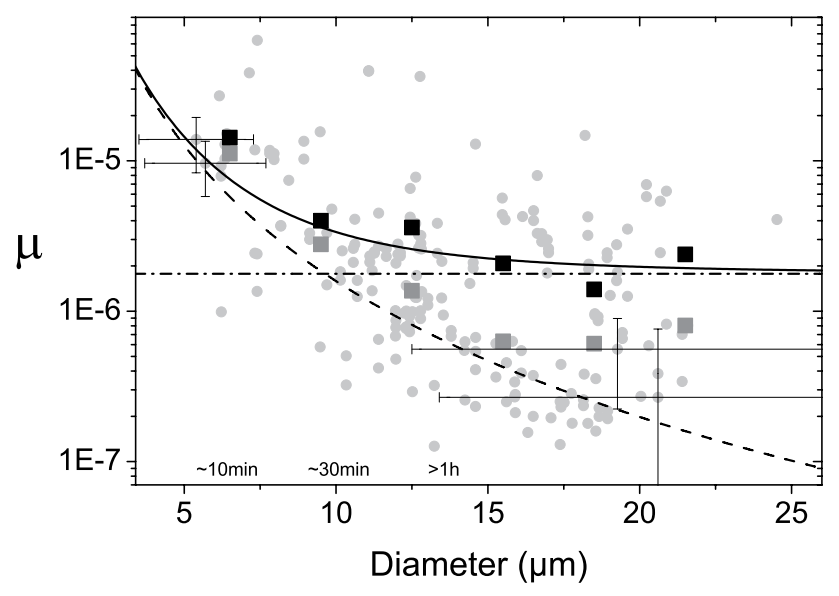

Fig. 4. Molar ratios of nitric acid to water in contrail ice particles $\mu$ versus mean ice particle diameter. Black (grey) squares represent means (medians) over $3 \mu \mathrm{m}$ size bins. For illustration, four data points are displayed with estimated measurement errors. Diameters $>20 \mu \mathrm{m}$ are uncertain due to the large-size cut-off of the FSSP100. Approximate contrail ages are inferred from the gas phase $\Delta \mathrm{NO}_{\mathrm{y}}$ data. Curves are model results; solid curve according to Eq. (1), dash and dash-dotted curves indicate limiting cases; see text for details.

aerosol particles as in Voigt et al. (2007), assuming an equilibrium composition of aqueous sulfuric acid droplets (diameter $\left.d_{0}=0.75 \mu \mathrm{m}\right)$ at $215 \mathrm{~K}$ and an $\mathrm{HNO}_{3}$ partial pressure $2 \times 10^{-6} \mathrm{hPa}$ (corresponding to $10 \mathrm{nmol} / \mathrm{mol}$ ) consistent with plume chemistry simulations (Kärcher et al., 1996). This value roughly determines the initial molar ratio of the nascent contrail ice particles. The resulting evolution of $\mu$ in the contrail as a function of the mean ice particle diameter $d$ (solid curve in Fig. 4) is given by (Kärcher and Voigt, 2006; Voigt et al., 2007):

$\mu=\mu_{0} \frac{1}{1+N}+\mu_{\infty} \frac{N}{1+N}, \quad N=\kappa\left(\frac{d}{d_{0}}\right)^{3}$,

with the ratio of ice and freezing aerosol particle bulk mass densities $\kappa$, the initial ice particle diameter $d_{0}$, and the trapped molar ratio $\mu_{\infty}$ as derived above. The ice particle dilution factor $N$ quickly takes values $\gg 1$ due to depositional growth. The first part of this relationship describes the initial decrease of $\mu \propto 1 / d^{3}$ by uptake of $\mathrm{H}_{2} \mathrm{O}$ (dashed curve); it becomes smaller than the second (trapping) contribution for $d>10 \mu \mathrm{m}$, at which point the trapped amount (dash-dotted curve) is approached, $\mu \rightarrow \mu_{\infty}$.

Except during the very short initial growth phase after ice nucleation, cirrus particles are usually large enough to render the aerosol component in Eq. (1) unimportant relative to the trapping component (Kärcher and Voigt, 2006). As shown here, the aerosol component is more prominent in persistent contrails, because mean contrail ice particle diameters stay relatively small owing to the large number density of ice particles compared to cirrus. Given the measurement uncer- tainties, the simple uptake model explains the observed trend in the mean values $\mu(d)$ in developing contrails fairly well. Variability in initial and ambient conditions may explain deviations of individual data points from the mean model curve. A set of data points between 10-20 $\mu \mathrm{m}$ following the median values seems to be well fitted by the dashed curve without trapping. We speculate that those measurements might be more representative of supersaturated inner contrail regions in which the local $\mathrm{HNO}_{3}$ gas phase mixing ratio was small due to inefficient mixing from ambient air.

\section{Summary and conclusions}

During the CIRRUS-III field campaign gas phase and ice phase reactive nitrogen, ice water content, and ice crystal size distributions were measured in contrails and cirrus at midlatitudes close to the tropopause. The temperatures and $\mathrm{HNO}_{3}$ partial pressures were in the ranges $210-230 \mathrm{~K}$ and $3-6 \times 10^{-8} \mathrm{hPa}$, respectively. The observed uptake of $\mathrm{HNO}_{3}$ in ice particles residing in the upper layers of frontal cirrus clouds confirms previous results from airborne field campaigns carried out in polar, midlatitude, and sub-tropical regions (Voigt et al., 2006).

On average the probed contrails contained twice as much ice-bound $\mathrm{HNO}_{3}$ as the cirrus clouds within $211-220 \mathrm{~K}$, $14 \mathrm{pmol} / \mathrm{mol}$ and $6 \mathrm{pmol} / \mathrm{mol}$, respectively. Thus, the mean fraction of total $\mathrm{HNO}_{3}$ in ice particles was considerably larger in the contrails $(6 \%)$ than in the cirrus layers $(3 \%)$. In young contrails (approximate age $<1 \mathrm{~h}$ ) this fraction was even higher (9\%). The measured molar ratios of $\mathrm{HNO}_{3}$ and $\mathrm{H}_{2} \mathrm{O}$ in contrail ice particles exceeded $10^{-5}$ for small particle sizes, or contrail ages. For older contrails, molar ratios approached the mean value of $2 \times 10^{-6}$ detected in the cirrus layers. Averaged over all detected contrails regardless of age, this caused the mean molar ratios in contrails to be about twice as large as in the cirrus clouds.

Motivated by our study, contrails may be regarded as an atmospheric laboratory to study $\mathrm{HNO}_{3}$ uptake during ice particle growth. Our data show that ice phase $\mathrm{HNO}_{3} / \mathrm{H}_{2} \mathrm{O}$ molar ratios decrease during contrail ageing. This dependence was explained by uptake of high levels of $\mathrm{HNO}_{3}$ into the freezing aerosol particles during ice formation in contrails and subsequent trapping of relatively low levels of ambient $\mathrm{HNO}_{3}$ in growing contrail ice particles. In young contrails with ages $<1 \mathrm{~h}$ or mean diameters $<10 \mu \mathrm{m}$, the ice phase $\mathrm{HNO}_{3}$ concentrations are therefore largely controlled by the jet engine $\mathrm{NO}_{\mathrm{x}}$ and $\mathrm{OH}$ emission indices. More airborne measurements with extended instrumentation are needed to study the dependence of $\mathrm{HNO}_{3}$ uptake on $\mathrm{HNO}_{3}$ partial pressure and to better quantify ice particle size distributions in developing contrails.

The results of this study help constrain chemicalmicrophysical models simulating heterogeneous chemistry in persistent contrails in order to constrain the impact of 
plume processing of $\mathrm{NO}_{\mathrm{x}}$ emissions on the chemical production or loss of ozone. Chemistry transport model simulations suggest that net upper tropospheric ozone production rates may decrease by $\sim 15-18 \%$ in the main midlatitude Northern Hemisphere traffic areas due to decreased aircraft-induced $\mathrm{NO}_{\mathrm{x}}$ perturbations when chemical plume processing effects are accounted for (Kraabøl et al., 2002). Uptake of $\mathrm{HNO}_{3}$ in contrail ice particles may further reduce ozone production by passivating $\mathrm{NO}_{\mathrm{x}}$.

Acknowledgements. This work was carried out within the HGFjunior research group AEROTROP (Impact of Aircraft Emissions on the heteROgeneous chemistry of the TROPopause region) and the DLR-project CATS (Climate-compatible Air Transport System). Part of this work was funded by the EU integrated project SCOUT O3 and the DFG SPP HALO 1294. The CIRRUS-III campaign was organized and mainly financed by FZ Jülich and the German Science Foundation (SFB 641 - The Tropospheric Ice Phase) and supported by DLR, the Max Planck Society, ETH Zurich, and Droplet Measurement Technology Inc. (Boulder, CO, USA). We thank Enviscope $\mathrm{GmbH}$ and the pilots and technicians of the Gesellschaft für Flugzieldarstellung (Hohn, Germany) for technical and logistical support during the campaign. We are grateful to M. Krämer for the organization of the campaign and to P. Spichtinger, F. Weidle, and G. Günther for the successful flight planning. We acknowledge fruitful discussions with D. Fahey.

Edited by: V. F. McNeill

\section{References}

Anderson, B. E., Cofer, W. R., Crawford, J., Gregory, G. L., Vay, S. A., Brunke, K. E., Kondo, Y., Koike, M., Schlager, H., Baughcum, S. L., Jensen, E., Zhao, Y., and Kita, K.: An assessment of aircraft as a source of particles to the upper troposphere, Geophys. Res. Lett., 26, 3069-3072, 1999.

Arnold, F., Scheid, J., Stilp, T., Schlager, H., and Reinhardt, M. E.: Measurements of jet aircraft emissions at cruise altitude I: the odd- nitrogen gases $\mathrm{NO}, \mathrm{NO}_{2}, \mathrm{HNO}_{2}$ and $\mathrm{HNO}_{3}$, Geophys. Res. Lett., 19, 2421-2424, 1992.

Bartels, T., Eichler, B., Zimmermann, P., Gäggeler, H. W., and Ammann, M.: The adsorption of nitrogen oxides on crystalline ice, Atmos. Chem. Phys., 2, 235-247, 2002, http://www.atmos-chem-phys.net/2/235/2002/.

Belyaev, S. P. and Levin, L. M.: Techniques for collection of representative aerosol samples, J. Aerosol Sci., 5, 325-338, 1974.

Borrmann, S., Luo, B., and Mishchenko, M.: Application of the T-matrix method to the measurement of aspherical (ellipsoidal) particles with forward scattering optical particle counters, J. Aerosol Sci., 31, 789-799, 2000.

de Reus, M., Borrmann, S., Bansemer, A., Heymsfield, A. J., Weigel, R., Schiller, C., Mitev, V., Frey, W., Kunkel, D., Kürten, A., Curtius, J., Sitnikov, N. M., Ulanovsky, A., and Ravegnani, F.: Evidence for ice particles in the tropical stratosphere from insitu measurements, Atmos. Chem. Phys., 9, 6775-6792, 2009, http://www.atmos-chem-phys.net/9/6775/2009/.

Fahey, D. W., Eubank, C. S., Hubler, G., and Fehsenfeld, F. C.: Evaluation of a catalytic reduction technique for the measure- ment of total reactive odd-nitrogen $\mathrm{NO}_{\mathrm{y}}$ in the atmosphere, J. Atmos. Chem., 3, 435-468, 1985.

Gao, R. S., Popp, P. J., Fahey, D. W., Marcy, T. P., Herman, R. L., Weinstock, E. M., Baumgardner, D., Garrett, T. J., Rosenlof, K. H., Thompson, T. L., Bui, T. P., Ridley, B. A., Wofsy, S. C., Toon, O. B., Tolbert, M. A., Kärcher, B., Peter, T., Hudson, P. K., Weinheimer, A. J., and Heymsfield, A. J.: Evidence that nitric acid increases relative humidity in low-temperature cirrus clouds, Science, 303, 516-520, 2004.

Gerz, T., Dürbeck, T., and Konopka, P.: Transport and effective diffusion of aircraft emissions, J. Geophys. Res., 103, 2590525913, 1998.

Hegglin, M. I., Brunner, D., Peter, T., Hoor, P., Fischer, H., Staehelin, J., Krebsbach, M., Schiller, C., Parchatka, U., and Weers, $\mathrm{U}$.: Measurements of $\mathrm{NO}, \mathrm{NO}_{\mathrm{y}}, \mathrm{N}_{2} \mathrm{O}$, and $\mathrm{O}_{3}$ during SPURT: implications for transport and chemistry in the lowermost stratosphere, Atmos. Chem. Phys., 6, 1331-1350, 2006, http://www.atmos-chem-phys.net/6/1331/2006/.

Heymsfield, A. J.: On measurements of small ice particles in clouds, Geophys. Res. Lett., 34, L23812, doi:10.1029/2007GL030951, 2007.

Kärcher, B.: Aircraft-generated aerosols and visible contrails, Geophys. Res. Lett., 23, 1933-1936, 1996.

Kärcher, B.: Supersaturation, dehydration, and denitrification in Arctic cirrus, Atmos. Chem. Phys., 5, 1757-1772, 2005, http://www.atmos-chem-phys.net/5/1757/2005/.

Kärcher, B., Abbatt, J. P. D., Cox, R. A., Popp, P. J., and Voigt, C.: Trapping of trace gases by growing ice surfaces including surface-saturated adsorption, J. Geophys. Res., 114, D13306, doi:10.1029/2009JD011857, 2009.

Kärcher, B., Hirschberg, M. M., and Fabian, P.: Small-scale chemical evolution of aircraft exhaust species at cruising altitudes, J. Geophys. Res., 101, 15169-15190, 1996.

Kärcher, B. and Voigt, C.: Formation of nitric acid/water ice particles in cirrus clouds, Geophys. Res. Lett., 33, L08806, doi:10.1029/2006GL025927, 2006.

Kondo, Y., Toon, O. B., Irie, H., Gamblin, B., Koike, M., Takegawa, N., Tolbert, M. A., Hudson, P. K., Viggiano, A. A., Avallone, L. M., Hallar, A. G., Anderson, B. E., Sachse, G. W., Vay, S. A., Hunton, D. E., Ballenthin, J. O., and Miller, T. M.: Uptake of reactive nitrogen on cirrus cloud particles in the upper troposphere and lowermost stratosphere, Geophys. Res. Lett., 30, 1154, doi:10.1029/2002GL016539, 2003.

Kraabøl, A. G., Berntsen, T. K., Sundet, J. K., and Stordal, F.: Impacts of $\mathrm{NO}_{\mathrm{x}}$ emissions from subsonic aircraft in a global three-dimensional chemistry transport model including plume processes, J. Geophys. Res., 107, 4655, doi:10.1029/2001JD001019, 2002.

Krämer, M., Schiller, C., Voigt, C., Schlager, H., and Popp, P. J.: A climatological view of $\mathrm{HNO}_{3}$ partitioning in cirrus clouds, Q. J. Roy. Meteorol. Soc., 134, 905-912, 2008.

Meier, A. and Hendricks, J.: Model studies on the sensitivity of upper tropospheric chemistry to heterogeneous uptake of $\mathrm{HNO}_{3}$ on cirrus ice particles, J. Geophys. Res., 107, 4696, doi:10.1029/2001JD000735, 2002.

Meilinger, S. K., Kärcher, B., and Peter, Th.: Microphysics and heterogeneous chemistry in aircraft plumes - high sensitivity on local meteorology and atmospheric composition, Atmos. Chem. Phys., 5, 533-545, 2005, 
http://www.atmos-chem-phys.net/5/533/2005/.

Neuman, J. A., Gao, R. S., Fahey, D. W., Holecek, J. C., Ridley, B. A., Walega, J. G., Grahek, F. E., Richard, E. C., McElroy, C. T., Thompson, T. L., Elkins, J. W., Moore, F. L., and Ray, E. A.: In situ measurements of $\mathrm{HNO}_{3}, \mathrm{NO}_{\mathrm{y}}, \mathrm{NO}$, and $\mathrm{O}_{3}$ in the lower stratosphere and upper troposphere, Atmos. Environ., 35, 5789-5797, 2001.

Popp, P. J., Gao, R. S., Marcy, T. P., Fahey, D. W., Hudson, P. K., Thompson, T. L., Kärcher, B., Ridley, B. A., Weinheimer, A. J., Knapp, D. J., Montzka, D. D., Baumgardner, D., Garrett, T. J., Weinstock, E. M., Smith, J. B., Sayres, D. S., Pittman, J. V., Dhaniyala, S., Bui, T. P., and Mahoney, M. J.: Nitric acid uptake on subtropical cirrus cloud particles, J. Geophys. Res., 109, D06302, doi:10.1029/2003JD004255, 2004.

Schiller, C., Krämer, M., Afchine, A., Spelten, N., and Sitnikov, N.: Ice water content of Arctic, midlatitude, and tropical cirrus, J. Geophys. Res., 113, D24208, doi:10.1029/2008JD010342, 2008.

Schlager, H., Petzold, A., Ziereis, H., Dörnbrack, A., Grimm, F., Arnold, F., and Schiller, C.: In-situ observations of particulate $\mathrm{NO}_{\mathrm{y}}$ in cirrus clouds for different atmospheric conditions, in: Proceedings of the European Workshop on Aviation, Aerosols, Contrails, and Cirrus Clouds, edited by: Schumann, U. and Amanatidis, G. T., European Commission, Brussels, Seeheim, Germany, 68-73, 1999.

Schröder, F., Kärcher, B., Duroure, C., Ström, J., Petzold, A., Gayet, J. F., Strauss, B., Wendling, P., and Borrmann, S.: On the transition of contrails into cirrus clouds, J. Atmos. Sci., 57, 464-480, 2000.

Schumann, U., Schlager, H., Arnold, F., Baumann, R., Haschberger, P., and Klemm, O.: Dilution of aircraft exhaust plumes at cruise altitudes, Atmos. Environ., 32, 3097-3103, 1998.

Talbot, R. W., Dibb, J. E., Scheuer, E. M., Kondo, Y., Koike, M., Singh, H. B., Salas, L. B., Fukui, Y., Ballenthin, J. O., Meads, R. F., Miller, T. M., Hunton, D. E., Viggiano, A. A., Blake, D. R., Blake, N. J., Atlas, E., Flocke, F., Jacob, D. J., and Jaegle, L.: Reactive nitrogen budget during the NASA SONEX mission, Geophys. Res. Lett., 26, 3057-3060, 1999.

Tremmel, H. G., Schlager, H., Konopka, P., Schulte, P., Arnold, F., Klemm, M., and Droste-Franke, B.: Observations and model calculations of jet aircraft exhaust products at cruise altitude and inferred initial OH emissions, J. Geophys. Res., 103, 1080310816, 1998.
Voigt, C., Kärcher, B., Schlager, H., Schiller, C., Krämer, M., de Reus, M., Vössing, H., Borrmann, S., and Mitev, V.: In-situ observations and modeling of small nitric acid-containing ice crystals, Atmos. Chem. Phys., 7, 3373-3383, 2007, http://www.atmos-chem-phys.net/7/3373/2007/.

Voigt, C., Schlager, H., Roiger, A., Stenke, A., de Reus, M., Borrmann, S., Jensen, E., Schiller, C., Konopka, P., and Sitnikov, N.: Detection of reactive nitrogen containing particles in the tropopause region - evidence for a tropical nitric acid trihydrate (NAT) belt, Atmos. Chem. Phys., 8, 7421-7430, 2008, http://www.atmos-chem-phys.net/8/7421/2008/.

Voigt, C., Schlager, H., Ziereis, H., Kärcher, B., Luo, B. P., Schiller, C., Krämer, M., Popp, P. J., Irie, H., and Kondo, Y.: Nitric acid in cirrus clouds, Geophys. Res. Lett., 33, L05803, doi:10.1029/2005GL025159, 2006.

von Kuhlmann, R. and Lawrence, M. G.: The impact of ice uptake of nitric acid on atmospheric chemistry, Atmos. Chem. Phys., 6, 225-235, 2006, http://www.atmos-chem-phys.net/6/225/2006/.

Weinheimer, A. J., Campos, T. L., Walega, J. G., Grahek, F. E., Ridley, B. A., Baumgardner, D., Twohy, C. H., Gandrud, B., and Jensen, E. J.: Uptake of $\mathrm{NO}_{\mathrm{y}}$ on wave-cloud ice particles, Geophys. Res. Lett., 25, 1725-1728, 1998.

Ziereis, H., Minikin, A., Schlager, H., Gayet, J. F., Auriol, F., Stock, P., Baehr, J., Petzold, A., Schumann, U., Weinheimer, A., Ridley, B., and Ström, J.: Uptake of reactive nitrogen on cirrus cloud particles during INCA, Geophys. Res. Lett., 31, L05115, doi:10.1029/2003GL018794, 2004.

Ziereis, H., Schlager, H., Schulte, P., van Velthoven, P. F. J., and Slemr, F.: Distributions of $\mathrm{NO}, \mathrm{NO}_{\mathrm{x}}$, and $\mathrm{NO}_{\mathrm{y}}$ in the upper troposphere and lower stratosphere between $28^{\circ}$ and $61^{\circ} \mathrm{N}$ during POLINAT 2, J. Geophys. Res., 105, 3653-3664, 2000.

Zöger, M., Afchine, A., Eicke, N., Gerhards, M. T., Klein, E., McKenna, D. S., Mörschel, U., Schmidt, U., Tan, V., Tuitjer, F., Woyke, T., and Schiller, C.: Fast in situ stratospheric hygrometers: A new family of balloon-borne and airborne Lyman- $\alpha$ photofragment fluorescence hygrometers, J. Geophys. Res., 104, 1807-1816, 1999. 